\title{
China Tax Scene
}

In this issue of the Newsletter, we report on the following topics:

- The State Administration of Taxation Sets up New Administrative Review Committee.

- Trial Preferential Policy for Enterprise Income Tax on Limited Partnership Venture Capital Entities.

- Individual Income Tax Policy on Dividend Income from Listed Companies.

- Supplementary Policy for the VAT Pilot Program.

\section{The state administration of taxation SETS UP NEW ADMINISTRATIVE REVIEW COMMITTEE}

The State Administration of Taxation (SAT) held a ceremony on 26 October 2012 for the establishment of the Administrative Review Committee (ARC). The Committee consists of sixteen SAT officials and eight external experts, and it will be responsible for reviewing complex key administrative review cases and setting administrative review policies.

Before the establishment of the ARC, a temporary committee would be formed for each administrative review case brought before the SAT. The establishment of the ARC is a clear indication that the SAT has recognized the importance of administration review. Hopefully, similar committees will be established at the lower level tax bureaus.

The ARC includes external experts from different backgrounds, including the Chief Editor of the China Tax News, a tax lawyer, certified tax agents, and professors in tax law, constitutional law and competition law. Interestingly, the SAT also called for the establishment of an expert review system in notices it issued earlier this year on the international tax administration system (Guo Shui Fa [2012] No. 41) and special tax adjustments (Guo Shui Fa [2012] Nos. 13 \& 16). The establishment of a permanent expert review committee shows that the SAT is paying more attention to opinions and suggestions from external tax practitioners and experts.

\section{TRIAL PREFERENTIAL POLICY FOR ENTERPRISE INCOME TAX ON LIMITED PARTNERSHIP VENTURE CAPITAL ENTITIES}

The Ministry of Finance (MOF) and the SAT jointly issued Cai Shui [2012] No. 67 (Notice 67) to provide preferential enterprise income tax treatment for legal persons who are partners in venture capital entities that are limited partnerships established in the Suzhou Industrial Park.

Pursuant to Notice 67, after the partnership entity has held shares in an unlisted small- to mid-size high and new technology enterprise (HNTE) for at least two years, the eligible partners can use $70 \%$ of their shares of the partnership entity's investment amount to offset the taxable income they receive from the partnership entity. The unused investment amount can be carried forward.

The preferential treatment under Notice 67 is effective for two years from 1 January 2012 to 31 December 2013.

\section{INDIVIDUAL INCOME TAX POLICY ON DIVIDEND INCOME FROM LISTED COMPANIES}

The MOF and the SAT issued Cai Shui [2012] No. 85 on 16 November 2012 to encourage long-term holding of listed company shares by individual investors.

Notice 85 provides a $50 \%$ individual income tax (IIT) reduction on dividend income earned from listed shares held by individual investors for more than one month but not more than one year, and a 75\% IIT reduction on dividend income earned from listed shares held by individual investors for more than one year.

Notice 85 will become effective on 1 January 2013.

\section{SUPPLEMENTARY POLICY FOR THE VAT PILOT PROGRAM}

The MOF and the SAT issued Cai Shui [2012] No. 86 (Notice 86) to provide certain supplementary policies for the VAT Pilot Program.

Among other things, Notice 86 clarified the categorization or tax treatment of certain services in certain special zones, including:

- Shipping agency services should be taxed as cargo transportation agency services.

- Transportation services provided between mainland China and Taiwan/Hong Kong/Macao and within Taiwan/Hong Kong/Macao by taxpayers registered in the pilot areas are subject to zero VAT rate. 
- Domestic cargo transportation, storage and loading services provided by taxpayers registered in the Tianjin Dongjiang Tax-Free Port can enjoy instant VAT refund; and
- Offshore outsourcing services provided by taxpayers registered in Pingtan are exempted from VAT starting 1 November 2012.

Notice 86 is effective as of 1 December 2012.

Jinghua Liu E Jon Eichelberger Baker \& McKenzie LLP, Beijing 